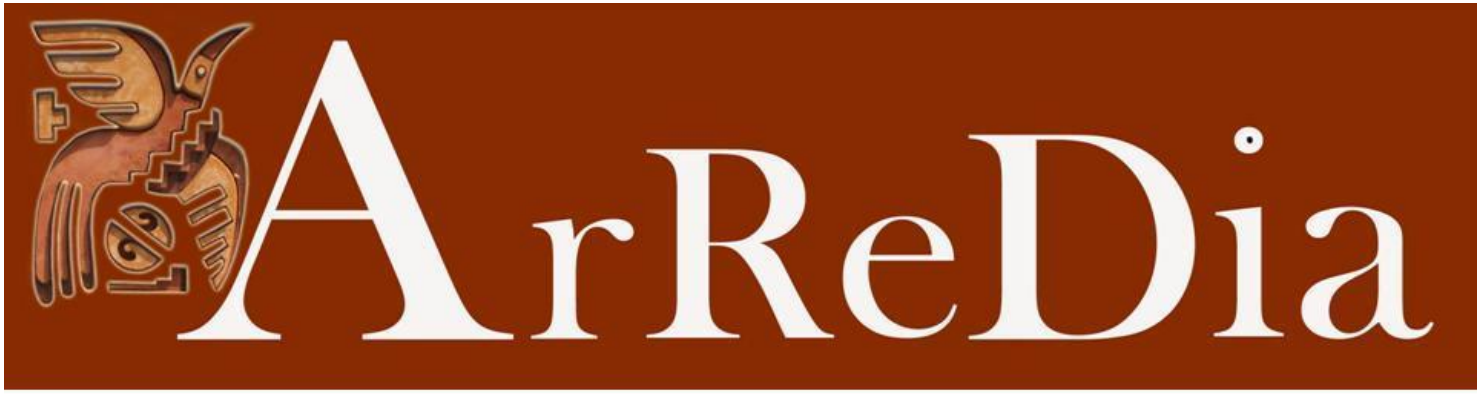

Revista da Faculdade de Comunicação, Artes e Letras / UFGD

\title{
ENTRE O PARAÍSO E O INFERNO: ASPECTOS DA LITERATURA DE COLONIZAÇÃO NO MATO GROSSO
}

\author{
BETWEEN PARADISE AND HELL: ASPECTS OF THE COLONIZATION \\ LITERATURE IN MATO GROSSO
}

(...) estamos condenados à civilização. Euclides da Cunha

\author{
Eliziane Ferreira Navarro ${ }^{i}$ \\ Universidade Federal do Mato Grosso
}

\begin{abstract}
RESUMO: Buscamos, neste estudo, desvendar aquilo que dá à obra Era um poaieiro de Alfred Marien, publicada em 1944, o caráter atemporal que excede os limites acerca da cultura de extração no extremo Oeste do Brasil, alcançando o tema da colonização como um todo. Interessa-nos, a partir da apresentação do contexto histórico de produção da obra, analisar o mito de criação que subjaz a composição textual de Marien em uma perspectiva comparatista entre os mitos Labirinto de Creta e Eldorado. Por último, nos atentaremos à recriação civilizatória enquanto transformação do caos em civilização. $\mathrm{O}$ aporte teórico utilizado perpassa, principalmente, os estudos de Flora Süssekind (2006), Lylia Galetti (2012), Carlos Gomes de Carvalho (2005), Junito Brandão (1987; 2002) e Mircea Eliade (1972; 1992; 1996).
\end{abstract}

PALAVRAS-CHAVE: mito, colonização, Alfredo Marien.

\begin{abstract}
We sought, in this study, to unveil what gives to the work Era um poaieiro by Alfred Marien published in 1944, the timeless character that exceeds the limits of the extraction culture in the extreme west of Brazil, reaching the theme of colonization as a whole. We are interested in analyzing the creation myth that underlies Marien's textual composition in a comparative perspective between the Creta and Eldorado Labyrinth myths. Finally, we will look at the civilization recreation as a transformation of chaos into civilization. The theoretical contributions used are mainly regarding to the studies of (2006), Lylia Galetti (2012), Carlos Gomes de Carvalho (2005), Junito Brandão (1987; 2002) and Mircea Eliade (1972; 1992; 1996).
\end{abstract}

KEY WORDS: myth, colonization, Alfredo Marien.

Ao voltar nossos olhos a uma narrativa publicada, pela primeira vez, em 1944 ambientada em um contexto totalmente distante dos holofotes do cânone, pretendemos demonstrar que a releitura feita por Alfredo Marien em Era um poaieiro acerca da tradição oral mato-grossense constitui um retorno à atemporalidade mítica.

Em Era um poaieiro, Alfredo Marien ambienta a história de seus protagonistas Brasilino e Teresa, no contexto histórico de Mato Grosso da década de 1930, durante o apogeu da poaia. Conta a história de Marien que Brasilino, recém chegado do serviço militar, e Teresa são jovens apaixonados que vivem nas proximidades de Barra do Bugres, pequena cidade próxima à atual capital do estado de Mato Grosso, Cuiabá, 
banhada pelos rios Bugres e Paraguai. O casamento dos dois, porém, só será possível depois da safra da poaia daquele ano, quando ele pretende ganhar o dinheiro necessário para ajudar a família e realizar seus próprios desejos. As dificuldades que permeiam esse ensejo definem-se na narrativa com a descrição da mata da poaia, espaço em que Brasilino recolhe-se durante, aproximadamente, três meses.

Alfredo Marien (1897-1975) é natural de Aix Provence, na França. Veio ainda criança para o Brasil, residindo, com os pais, na cidade de Limeira, no estado de São Paulo, em 1905. Com o pai, aprendeu o ofício de jardinagem que lhe foi útil, rendendo-lhe o emprego de ajudante na construção do Campo de Santana, em frente à Central do Brasil, no Rio de Janeiro. Hábil com linguagens falava, lia e escrevia em outros oito idiomas dentre as quais: português, latim, aramaico, hebraico, grego, inglês, guarani e espanhol.

Apaixonado por Mato Grosso, onde viveu por muitos anos, o escritor reproduz na obra, por meio da captação de lendas e costumes locais, a identidade de uma gente esquecida nos confins do país. Era um poaieiro é um amálgama de lendas e rituais que corroboram para o entendimento de que a cultura mato-grossense, inserida no repertório brasileiro, é uma fonte de elementos que fundamentam uma literatura rica, tal qual àquela proveniente das culturas colonizadoras.

\section{O imaginário e a cultura de extração}

É Gaston Bachelard que defende a necessidade de imaginar como primordial para se habitar o vazio social (1996). Nos séculos XV e XVI, a Europa vivia o esplendor do renascimento e das grandes navegações. $\mathrm{O}$ Novo Mundo descoberto, por sua vez, era um lugar de natureza intocada, o povo cuja cultura exótica fugia totalmente dos padrões europeus, tratava-se de um espaço de aventura fora do seu espaço de civilização, onde tudo era possível.

A descoberta das Américas também denotava possibilidade de fortuna. Além do clima temperado, interessante para o europeu que sofre com o inverno rigoroso, o ouro seria facilmente encontrado no Novo Mundo. Vale lembrar que o europeu já tinha em seu imaginário a tradição e o encanto pelo ouro como símbolo de poder e econômico. A falta de importância que os nativos pareciam dar àquelas riquezas, sem empregarlhes valor econômico, transmitia a impressão de tamanha abundância que se tornara comum, cotidiana. Em Viagem ao Brasil, Maximiliano de Wiel Neuwied afirma: 
Os aventureiros europeus, ávidos de ouro, excitados por essas narrativas fabulosas, arriscaram-se a percorrer todas as partes do Novo Mundo à procura desse paraíso tão ardentemente desejado; para achá-lo, penetraram nas mais distantes florestas desse vasto continente, e muitos nunca voltaram. Devem-se, portanto, a essa sede de ouro dos espanhóis e portugueses as poucas noções incompletas que se possuem sobre as condições e a geografia dessas solidões interiores da América meridional. A maior parte dos países desse continente goza da tradição de serem regiões que encerram no seu interior grandes riquezas em ouro. La Condomine fala-nos de um "Dorado" ou duma "Lagoa Dourada"; Humboldt e outros escritores também os mencionam; tradição semelhante reina nas margens do Mucuri e do rio dos Ilhéus. (SUSSEKIND, 1990, 142)

É como se o descobrimento de novas terras tivesse dado margem à crença em novas possibilidades. Se há esse povo exótico, essas terras ricas, se eles haviam chegado tão longe, não era possível descartar a possibilidade de encontrar ainda mais riquezas. E isso motivava os sonhadores que passaram a se adentrar, cada vez mais, no continente em busca de jazidas fantásticas, em busca do El Dourado.

Diz Johnni Langer (1997) que o mito do El Dourado remonta aos anos de 1531 ou 32 quando Diego de Ordaz toma conhecimento de um lugar repleto de pedras preciosas demoninado País de meta. Mais tarde, um índio no Equador falaria da existência de um cacique que se banhava em uma lagoa de ouro, no lugar hoje chamado de Província do El Dorado. Gonçalo de Olviedo, em 1541, faz o primeiro relato escrito do mito. O fato de algumas expedições terem encontrado objetos de ouro nessa região fez com que o imaginário crescesse na cabeça dos aventureiros que chamavam El Dourado uma cidade inteira repleta de ouro.

É entre 1580 a 90 que um trabalhador de Ordaz, que havia ficado perdido nas florestas e retorna anos depois, faz revelações sobre a cidade de ouro. Nesse ínterim, o manuscrito sobre o assunto The discoverie of the large, rich and beautiful empire of guiana, with a relation of the great and Golden city of Manoa (1596) de Walter Raleigh fica famoso na Europa, aguçando ainda mais o interesse dos aventureiros. $\mathrm{O}$ desenvolvimento da imprensa e as narrativas de viagem pelas novas terras descobertas na Europa do século XV aguça o interesse pelas partes desconhecidas do mundo.

O El Dourado, então, virou símbolo de um arquétipo no imaginário popular, sendo representado, no mundo concreto, por um lugar remoto com alguma riqueza inestimável. É assim que homens se colocaram em perigo em nome de um ideal, ora buscando a terra de Manoa até a fonte da juventude como descrito por Umberto Eco em Histórias da Terra e 
Lugares Lendários (2003). No Brasil colonial, muitas expedições foram criadas para buscar o manancial de pedras preciosas, sobretudo nos séculos XVI ao XVIII.

É bem verdade que pintar as colônias como "um lugar de grandes oportunidades" era um bom negócio para os governantes. Com o descobrimento das Américas, a forte crise que se instaurou na Europa, consequência da devastação das guerras, houve grande comoção por parte do governo para trazer pessoas para povoar as colônias. Para isso eram feitas propagandas exorbitantes que podem ter contribuído para o descontentamento da população que aqui chegava. E assim foi colonizado o Brasil.

\begin{abstract}
(...) houve, realmente, durante as primeiras décadas do século passado, um grande interesse em atrair mercenários, para reforçar as forças militares imperiais, e camponeses alemães, pressionados por más colheitas, impostos pesados e pelo alto grau de divisão da propriedade no seu país, para trabalhar como colonos no Brasil. E foram utilizados para esse fim desde agentes especializados, como Georg Anton Alysvn Schaffer que publicaria em 1824 o livro O Brasil como Império independente -, até canções de incentivo às viagens, que transformavam a terra brasileira em verdadeira Terra da Promissão, onde haveria ouro como areia, as batatas seriam do tamanho de uma cabeça, o café cresceria em todas as árvores e o verde seria eterno. (SUSSEKIND, p. 22)
\end{abstract}

As propagandas também serviam para criar no imaginário do homem a ideia do pote de ouro no final do arco-íris. Em um lugar em que a vida se fazia difícil mesmo para os homens com seus direitos legais e liberdade resguardados, pensemos na comoção que é ouvir sobre uma terra de oportunidades para quem estava preso ou mal conseguia se alimentar por causa da crise. Com a descoberta de algumas jazidas, convencionou-se pintar a colônia com nuances de um El Dorado.

Processo tardio, mas semelhante se deu em Mato Grosso. Esse comportamento se transferirá para o relacionamento metrópole e interior, quando Mato Grosso foi compreendido como terra da riqueza e da promissão, semelhante ao canto da sereia que convidou os viajantes naturalistas, embalados pela ideia de que o Brasil não seria tão distante, como fala Flora Süssekind (1990). Envolvidos pela propaganda e pela construção de um imaginário popular que dava conta de grandes riquezas, diversas expedições de estrangeiros aqui vieram. Um exemplo da propaganda extravagante difundida acerca de Mato Grosso, relatado por Joseph Barboza de Sáh e que faz parte da catalogação de Carlos Gomes de Carvalho: 


\begin{abstract}
Segundo o padre André dos Santos Queiros, propagandista do MT "era uma trombeta que tudo atroava (e) soou a fama do Cuyabá até os fins do orbe, passando dos limites do Brasil a Portugal e daí aos reinos estrangeiros, tanto que chegaram as exagerações fabulosas dizendo se que no Cuyabá serviam os grenetes de chumbo nas espingardas de matar veados. Que de ouro eram as pedras em que nos fogões se punham as panelas e que para o apurar não era necessário mais do que arrancar as touças de capim que nelas vinham pegadas as folhetas e isto de arrancar-se capim e virem as vezes granetes de ouro pegados às raízes foi visto muitas vezes" (CARVALHO, 2005, p.9)
\end{abstract}

Os minérios na Serra dos Martírios, por exemplo, trouxeram inúmeros desbravadores, como é o caso da Serra do Roncador - Xingu e do rio Araguaia. Ainda de acordo com Carvalho, Percy Harryson Fawcet fez três investidas, em1920, 1922 e 1925 a procura de vestígios da Atlântida no Brasil, sempre recusando a ajuda ofertada pelo governo brasileiro. $\mathrm{O}$ inglês nunca voltou da sua última tentativa.

Diante desse contexto, quando o lugar não tem riquezas, o imaginário cria. É o que é representado no conto "As minas de prata" de José de Alencar (1953), que, ao encontrar as minas que seu pai lhe falava e perceber que não tinha nada, cria a ilusão de uma trilha de diamantes na areia, já que se verificou que a mina de prata não era verdade. A crença na possibilidade de encontrar essas riquezas, nesse caso, é o motivo gerador de um propósito de vida, e, ao verificar a não existência onde esperava encontrar, adapta-se à história para a crença não deixar de fazer sentido. A esse respeito, o antropólogo Lévi-Strauss que viajou por Mato Grosso na década de 30 conta:

Em Barra do Bugres, povoado do Mato Grosso ocidental no alto Paraguai, vivia um 'curandeiro', que curava mordidas de cobra; principiava picando o antebraço do doente com dentes de sucuri. Em seguida, riscava no chão uma cruz com pólvora de espingarda, que acendia para que o doente esticasse o braço na fumaça. Por último, pegava algodão carbonizado de um 'artifício' (isqueiro de pedra cujo pavio é feito de um chumaço de algodão amassado num recipiente de chifre), embebia-o de cachaça que o doente tomava. Mais nada.

Um dia, o chefe de uma 'turma de poaieiros' (grupo de colhedores de ipecacuanha, planta medicinal), assistindo a essa cura, pede ao curandeiro que espere até o próximo domingo pela chegada de seus homens que, certamente, quererão todos ser vacinados (a cinco mil réis cada um, ou seja, cinco francos de 1938). O curandeiro aceita. No sábado de manhã, ouve-se um cachorro uivar fora do 'barracão'. O chefe da turma despacha um 'camarada' para reconhecimento: é uma 'cascavel', cobra de chocalho, enfurecida. Manda o curandeiro capturar o réptil; o outro se recusa a fazê-lo. O chefe zanga, 
declara que sem captura não haverá vacinação. $O$ curandeiro obedece, estende a mão na direção da cobra, é picado e morre. Quem me conta essa história explica que fora vacinado pelo curandeiro e que em seguida deixou-se morder por uma cobra para controlar a eficácia do tratamento, com absoluto sucesso. É verdade, ele acrescenta que a cobra escolhida não era venenosa. Transcrevo o relato porque ilustra muito bem essa mistura de malicia e ingenuidade - a propósito de incidentes trágicos tratados como pequenos acontecimentos da vida cotidiana que caracteriza o pensamento popular do interior do Brasil. Não devemos nos enganar quanto à conclusão, absurda só na aparência. $O$ narrador raciocina como o chefe da seita neomuçulmana dos Ahmadi, que eu iria ouvir mais tarde durante um jantar para o qual ele me convidara, em Lahore. Os Ahmadi afastam-se da ortodoxia, sobretudo mediante a afirmação de que todos os que se proclamaram messias no decorrer da história (entre os quais incluem Sócrates e Buda) o foram efetivamente: caso contrário, Deus ter-lhes-ia castigado a imprudência. Da mesma forma, talvez pensasse meu interlocutor de Rosário, se a magia do curandeiro não fosse real, os poderes sobrenaturais provocados por ele fariam questão de desmenti-lo tornando venenosa uma cobra que em geral não era. Já que a cura era considerada mágica, num plano igualmente mágico ele, afinal de contas, a controlara de modo experimental. (CARVALHO, 2005, p. 402-403)

Considerando o conhecimento, as expectativas e a religiosidade, os viajantes encontraram aqui o inexplicável. É um fenômeno de demanda social, os europeus propriamente tinham necessidade de continuar acreditando que as expedições não eram em vão. A própria cultura de extração depende da crença de que não se pode parar, de que é preciso ir além para se conquistar mais. É essa a realidade vivida pelos poaieiros e seus apegos às crenças e à tradição popular, é preciso acreditar para que todo o desconforto da vivência em um lugar inóspito como Mato Grosso e, mais ainda, dentro das florestas, valha a pena.

\section{Uma atualização mítica}

Ao tratar da imutabilidade dos temas nas narrativas romanescas, Mircea Eliade, citado por Junito Brandão (2001) assegura:

Para Mircea Eliade, os temas dos relatos épicos e das narrativas romanescas não mudam, os modelos transmitidos do mais longínquo passado não desaparecem [...] Todas as criações (uma casa, um filho, um poema) têm como modelo a cosmologia (isto é, a regeneração - ou reintegração - na perfeição original). Trata-se, sempre, de um encaminhamento iniciático: retorno individual à origem, passagem, renascimento. Para Eliade, com efeito, a literatura é a expressão de uma revolta contra o tempo histórico, e o personagem literário escapa a seus condicionamentos. A criação artística é 
um esforço para recriar a linguagem a fim de permitir a passagem do verbal ao formal, o acesso à sacralidade, pois que se trata de viver o universal e o intemporal (BRANDÃO, 2001, p. 587).

Dessa forma, a criação literária pode ser vista como um retorno às primícias, por guardar em sua estrutura elementos que remetem à atemporalidade. A releitura desses símbolos que fazem os modelos clássicos transmitidos pela literatura moderna se refere, sobretudo, se considerarmos os pressupostos defendidos por Joseph Campbell (2008), à função pedagógica do mito, ou seja, além de estabelecer a ordem, contribuir para a maturação do homem nas etapas de passagem, o mito é também a representação do desejado, explica o universo e suas relações, além de conciliar a consciência humana com a natureza.

E é isso que essa atualização mitológica recria, ao imprimir no sertão de Mato Grosso, elementos que ensejam correlação com os grandes feitos da Antiguidade Clássica. Essa imutabilidade é constituída diante da fragilidade do homem que, mesmo passado tantos anos, ainda precisa que o sobrenatural lhe explique as condições da vida. Uma das principais funções do mito dentro de uma sociedade é legitimar a estrutura de poder. Compreendido assim, não é, principalmente, o homem que está no ápice da pirâmide social que precisa do mito como explicação para o imutável, e sim a parte que sofre as consequências, os prejuízos dessa imutabilidade.

Ao buscar um diálogo com a mitologia grega, conforme Junito Brandão (2002) e Edith Hamilton (1942) temos a narrativa do amor do casal real Teseu, filho de Egeu rei de Atenas e a princesa Ariadne, filha de Minos de Creta. O príncipe de Atenas, porém, foi criado por sua mãe no sul da Grécia, longe das regalias do palácio. Esta ficou incumbida de, sendo Teseu um rapaz, contar-lhe de sua origem e prepará-lo para sua primeira missão: remover uma grande pedra em busca de uma espada enterrada e só então, partir à procura de seu pai. Tendo realizado facilmente a empreitada Teseu almejava ser reconhecido como grande herói:

Recusou, portanto, firmemente o barco que a sua mãe e o avô lhe ofereciam, afirmando que uma tal viagem constituiria uma desprezível fuga aos perigos; iria a Atenas, sim, mas por terra! O caminho foi longo e muito acidentado, pois, nas estradas, era frequente encontrarem-se bandidos, que assaltavam os viajantes.Todavia ele matara-os a todos, não deixara vivo nem um sequer que perturbasse de novo qualquer outro viajante. (HAMILTON, 1942, p.216)

As diversas facetas de Teseu seja como rei mítico, destruidor de monstros, guerreiro destemido ou amante são frequentes na literatura. Ao 
chegar a Atenas, o herói toma ciência de que de nove em nove anos, quatorze jovens eram oferecidos como sacrifício ao Minotauro, um elemento com cabeça de touro e corpo humano, mantido preso em um labirinto construído por Dédalo e se propõe a enfrentar o monstro. Este sacrifício é fruto da desgraça acontecida quando Andrógeo, filho de Minos, sendo hóspede do rei Egeu, morreu ao fazer parte de uma expedição para matar um touro. Arrasado, Minos invadiu Atenas e sentenciou o sacrifício.

O Minotauro, por sua vez, era o filho da traição da esposa do rei Minos com um belo touro que fora dado pelo deus Posídon ao seu marido. Este, estando encantado pela beleza do touro o poupou de ser sacrificado, ocasionando a ira de Posídon. (HAMILTON, 1942).

Iniciaremos a descrição dos pontos convergentes, primeiro pela construção das personagens protagonistas: um casal apaixonado formado por um herói guerreiro e uma fiandeira à espera do regresso de seu amado. Ambos os heróis, Teseu e Brasilino, devem cumprir uma tarefa, voltarem vitoriosos e só assim alcançarem seus intentos dentro da sociedade em que estão inseridos. Esta tarefa consiste em enfrentar um caminho obscuro, desconhecido, à mercê de um monstro híbrido e de toda sorte de sofrimentos que a luta requer.

O sacrifício de Teseu é próprio dos heróis mitológicos, que por sua posição como filho do rei, se oferece para ir ao labirinto enfrentar o Minotauro. A concepção do herói mitológico implica em um homem corajoso, cuja força e nobreza o equipara a um ser acima dos meros humanos. Neste caso, a coragem e disposição de Teseu livra a sociedade de um cenário de choro, aflições e lamentações e faz dele um homem digno de admiração em seu contexto.

Ao construir em solo mato-grossense a história de um herói, que assim como Teseu na mitologia grega, tem qualidades que se sobressaem em sua sociedade, que se sacrifica em nome de sua família e tem como dever, para alcançar a benção desejada, a vitória em uma tarefa em um espaço desconhecido, o autor remete-nos à lembrança de outros heróis com características semelhantes, distante somente naquilo que o próprio mundo em que viveram os diferenciou.

A definição de herói e suas atribuições, no entanto, são valores passíveis de transformação, sobretudo quando se considera uma passagem de tempo tão longa como entre a Grécia Antiga e o Mato Grosso na década de 1930. Essas mudanças nos valores socioculturais implicam em mudanças nas características que definem as personagens. $O$ interior do Mato Grosso no século XIX requer, por sua vez, um herói desbravador, 
capaz de se sustentar íntegro dentro de um contexto social financeiramente opressor. Assim, o sertanejo nem sempre é o herói, tal como vemos o próprio Gonçalo, mas as características do homem sertanejo preenchem os moldes do herói nacional.

A figura do sertanejo, entretanto, não estava dissociada da barbárie, porém uma vez civilizado poderia ser de grande valor à Coroa. Essa relação de serventia, inclusive, é a relação que tio Chico reproduz, ao sinalizar que Brasilino poderia trazer uma índia que serviria para os serviços domésticos na feitoria, como discutido no capítulo anterior.

Na obra de Marien, Brasilino enfrenta as matas da poaia porque o heroísmo do homem do século XIX é manter o sustento da casa e cuidar dos seus, como bem demonstra o poaieiro em um diálogo com Teresa em que diz “(...) No fim da safra se Deus quiser, estarei de volta com o dinheiro... E logo estaremos casados! (...)” (MARIEN, 2008, p. 33). O intento de sua predisposição é ganhar dinheiro, elemento tão necessário no sistema capitalista vigente, que é o recurso que permitiria a solução de seus problemas familiares e realização de seu sonho maior que é o casamento com Tereza.

Em Era um poaieiro, Brasilino também é um ser íntegro e admirável. $\mathrm{O}$ autor denota sua superioridade ao descrever a amizade entre ele e seu cão quando diz “(...) Quando ao Guará era de uma fidelidade comovedora. Acompanhava-o por toda parte, ficando longas horas a olhar para ele, como se Brasilino fosse um deus." (MARIEN, 2008, p. 37).

Ao criar o protagonista de sua obra, há, em Marien, um cuidado em exaltar a dignidade e superioridade de Brasiliano, sobretudo, se comparado aos outros personagens que apresentam vícios ou agem em desconformidade com os valores morais, ele é, então, criado como herói. Essas comparações servem para enaltecer, ainda mais, as qualidades de Brasilino, que é descrito como um patrão íntegro, noivo fiel, filho e amigo dedicado principalmente quando sua descrição contrasta com a de Gonçalo, seu inimigo.

Há, inclusive, um capítulo inteiro denominado "Trato é trato" em que Brasilino, ao saber do aumento no preço da poaia, tendo combinado um valor com seus companheiros, mesmo eles ratificando que Brasilino deveria pagar-lhes o que fora combinado, divide o lucro, sem obrigação alguma. O jovem patrão demonstra assim, que mesmo tendo meios para alcançar, mais rapidamente, o dinheiro que garanta sua volta para casa, ele não sucumbe à oportunidade de reproduzir o comportamento da classe opressora própria do capitalismo selvagem. 
Ao falarmos do homem que habitava os sertões mato-grossenses é preciso lembrar o que diz Abílio Leite de Barros na obra Gente Pantaneira (1998) publicada em 1998. Antes de o mundo voltar sua atenção ao Pantanal como um dos últimos redutos naturais do Brasil, em caráter de denúncia, o autor fala sobre o elo entre o homem e a natureza, além da amizade entre empregador e empregado, cujo vínculo provinha não só do fato de ambos dividirem o cotidiano trabalhando lado a lado, mas também do isolamento de viver em uma das partes mais inóspitas do país. Segundo ele:

\begin{abstract}
Além da intimidade do convívio estreito, outro elemento de forte coesão interna nos primeiros tempos foi o isolamento. Não havia movimentação de estranhos, não havia forasteiros. $\mathrm{O}$ grupo deveria bastar a si mesmo. Assim, havia, sem dúvida, uma dependência mútua entre patrões e empregados, até para as mínimas necessidades de convívio social. Essa dependência há de tê-los feito solidários. A solidão é professora: ensina a ouvir, ensina a tolerar, a ver o outro, ensina a ajuda mútua. (LEITE, 1998, p. 166).
\end{abstract}

Essa camaradagem e elo entre patrão e empregado são perceptíveis na obra aqui analisada quando pensamos o relacionamento de Brasilino e os demais sertanejos.

Outro ponto de encontro entre o labirinto de Creta e Era um poaieiro é a espera a que se submetem as personagens femininas Ariadne e Teresa. As duas mulheres se veem sem alternativa a não ser esperar que seus amados vençam a tarefa que lhes esperam e retornem para estar com elas. A condição de aparente insignificância dessas mulheres se desfaz ao pensarmos o ofício de fiandeira que as aproxima. Teresa tece uma rede para que Brasilino pense nela enquanto está na mata. A rede de Teresa é usada para embalar os sonhos do amado, mas depois é usada como mortalha para o corpo de Brasilino, cumprindo assim o destino de outra importante peça da mitologia grega, a mortalha que Penélope tece de dia e desfaz a noite, em Odisséia (2005). Ariadne dá a Teseu um fio para que este não se perca no labirinto. Escondido sob o signo do objeto do novelo está a única possibilidade do retorno de Teseu. Sua condição de herói triunfante está intrinsecamente ligada à ajuda de Ariadne. Em outros termos, Ariadne está dando ao parceiro o elo entre a consciência e a inconsciência, entre a vida e a morte.

Compreendidas sob o arquétipo da fiandeira, essas mulheres têm sobre si o papel de senhoras do destino, pois todo seu trabalho é desenvolvido mediante o manejo do fuso, um símbolo cíclico da passagem do tempo. Outro ponto que interliga essas duas personagens femininas é o 
abandono a que se sujeitam suas famílias em nome do amor. Teresa foge de casa quando seu pai tenta casá-la com Gonçalo. “(...) Então fingi que estava pegando um frango, atrás da cozinha e escapei, correndo, no cerrado... Agora, quero ficar com minha madrinha, com você (...)" (MARIEN, 2008, p.165). Já Ariadne foge com Teseu que depois também a abandona. A fuga de casa que representa a busca pela oportunidade de escolher seu próprio destino configura-se também como uma revolta contra a estrutura patriarcalista vigente, na qual a autoridade do pai sobre a filha era total.

Visto como um lugar desabitado, de povos não civilizados, perigos iminentes, o sertão seria a própria representação do caos. Mato Grosso, há meses de viagem dos grandes centros, era conhecido pelas minas auríferas que se contrastavam com a barbárie. Esse espaço praticamente desabitado, o isolamento e a população nativa contribuíam para a visão, muitas vezes, depreciativa do local. A ausência dos basilares que os colonizadores julgavam fundamentais, tais quais as leis imperiais, a fé católica e a própria obediência ao rei, dava à região um aspecto exótico, onde tudo era possível. Trata-se de um espaço vasto, repleto de crenças próprias e características peculiares. Pitoresco, misterioso e longínquo, recheado de elementos míticos.

No que diz respeito aos aspectos congruentes entre o labirinto de Creta e a floresta da poaia que se estende "pela margem direita do rio Paraguai, desde a cidade de São Luiz de Cáceres, por dezenas de léguas rio acima até a povoação da Barra do rio Bugres" (MARIEN, 2008, p. 57) é o próprio Marien que sugere a leitura da floresta como um labirinto:

\footnotetext{
Cada ano ficam alguns poaieiros perdidos, extraviados nos labirintos das corixas, ou devorados pelas feras, ou vitimados pelas moléstias, mas não vencidos, nessa luta do homem contra a natureza, pelos vermes que lhes roubam as forças, pela febre que os prostra, pelas feridas bravas que lhes corroem os corpos de bronze. (MARIEN, 2008, p.58)
}

Esta ida à floresta e ao labirinto, por si só, remonta ao rito de passagem, que consiste nas celebrações que marcam as mudanças dos jovens, sobretudo nas sociedades primitivas. A ida à mata predetermina o casamento de Brasilino, ele precisa realizar a tarefa ou não alcançará a graça necessária para propor casamento à Teresa. Semelhante à narrativa clássica, Teseu precisa vencer o Minotauro para livrar Atenas, pois esta é a sua função como herói, como se viu. A entrada no labirinto, em ambas as histórias permeia o nascimento de um novo homem, é o início da travessia, cujo fim, no entanto, é a morte. Cumprindo sua função social de 
herói, ambos saem vencedores das suas respectivas tarefas. Teseu mata o Minotauro e volta para os braços de Ariadne. Brasilino vence a floresta e volta para cumprir o propósito de se casar com Teresa.

Uma vez compreendido o contexto em uma visão maniqueísta é preciso considerar a existência entre o bem e o mal e, sobretudo, a vitória de um em detrimento ao outro. Dessa forma, só é possível pensar a existência de um herói se houver um monstro vencido, quer seja pela astúcia seja pela força. Assim, é preciso conceber a existência desses seres, que nas narrativas aqui analisadas consistem em seres híbridos. O último ponto que aproxima as duas narrativas é, portanto, os dois representantes do lado mal da lógica binária grega. Trata-se de dois híbridos, o Minotauro, metade homem metade touro e o pé de garrafa, metade homem metade lobo, representando assim, a ameaça ao herói.

A própria noção de opostos constitui-se como proveniente na concepção de Scholles e Kellogg (1977), aos rituais de fertilidade que se baseiam nesse conflito entre vida e morte, bem e mal. Assim, qualquer narrativa que anseie servir de modelo para a posterioridade precisa ser regida por polos opostos e contrastantes que atestem, após confronto, a superioridade de um em correspondência ao outro. É relacionado a esse padrão que podemos julgar a representação do vilão e do mocinho, do que é justo e injusto e, sobretudo, do que é honra e o que é castigo.

Essa predisposição à alteridade é elemento convergente perceptível nas duas obras. O Pé de Garrafa é o protetor da floresta e, ao mesmo tempo em que a protege dos desmatamentos garante a subsistência do poaieiro, ele os assusta e é visto como mais uma ameaça para os meses na escuridão da mata.

A natureza também é apresentada sob uma perspectiva dupla, pois pode ser compreendida mediante o arquétipo da grande-mãe, e dessa forma, vista como a resposta para a busca de autonomia do homem, mas também tem seus momentos de grande opressora do pobre homem que, com toda sua coragem, ainda é frágil diante de sua face furiosa. Ao descrever as especificidades do labirinto, Hamilton diz:

\footnotetext{
Uma vez lá dentro, podiam seguir-se infinitamente os seus caminhos ziguezagueantes sem jamais se encontrar a saída. Os jovens atenienses, à chegada a Creta, eram conduzidos para o Labirinto e abandonados ao Minotauro. Não havia possibilidades de escapar! Qualquer que fosse a direção que se tomasse podiam estar a encaminhar-se para o monstro; mas se não se deslocassem ele também podia surgir de um momento para o outro. (HAMILTON, 1941, p.218)
} 
O labirinto em Creta se configura, também, como o espaço protetor, na medida em que impede a fuga e o ataque do Minotauro, ao mesmo tempo em que é o lugar onde o guerreiro se perde. Percebemos aqui que a narrativa de Marien perpassa a complexidade inerente à lógica binária. Os polos extremos opostos são desafiados aqui, o bem não é só bem, e o mal não é só mal.

A própria binaridade em relação à natureza relaciona-se com vertentes mitológicas distintas. Compreendida na concepção da natureza enquanto espaço inóspito que subjuga o homem está a referência ao mundo de trevas para onde o homem e a mulher foram sentenciados a sobreviver com dores e trabalho árduo durante toda a vida, depois de transgredirem e serem expulsos do paraíso perfeito pelo único Deus da mitologia Cristã. Nessa vertente, conforme Thomson Highway, que faz um estudo acerca da mitologia Cree no Canadá, "space, in other words, was taken from us, and time is our curse" (HIGHWAY, 2003, p.32) ${ }^{1}$. Concebida como realização de uma deusa que:

\begin{abstract}
"kills with earthquakes, she destroys with hurricanes, she destroys with famine and starvation and drought and AIDS, tuberculosis, meningitis, all manner of disorders, physical, emotional, mental, spiritual and otherwise (...) one really has to be quite careful but... in the end, she is beautiful and kind and, because of it, to be respected, revered, thanked." (HIGHWAY, 2003, p.42)
\end{abstract}

A natureza americana, na mitologia indígena ainda é o paraíso na terra, uma vez que não há narrativa de expulsão. Sendo assim, conforme Thomson Highway "it is not a curse from an angry male. It is a gift from a benevolent female god." (HIGHWAY, 2003, p.46) 3

Esta perspectiva salienta que o europeu que, impondo sua mitologia, sua cultura, seus modos de produção e, acima de tudo, sua discutível superioridade em detrimento à colônia, reprimiu um povo, rebaixando a deusa mãe natureza em detrimento ao deus homem. Nas palavras de Highway "at that point, the circle of matriarchy was punctured by the straight line of patriarchy, the circle of the womb was punctured, most

\footnotetext{
${ }^{1}$ Espaço, em outras palavras, foi tirado de nós, e o tempo é a nossa maldição. (tradução nossa).

${ }^{2}$ Mata-se com terremotos, ela destrói com furacões, ela destrói com fome e fome e seca e AIDS, tuberculose, meningite, todos os tipos de distúrbios, físicos, emocionais, mentais, espirituais e de outra forma (...) realmente tem que ter bastante cuidado, mas ... No final, ela é linda e amável e, por causa disso, precisa ser respeitada, reverenciada, agradecida. (tradução nossa)
}

${ }^{3}$ Não é uma maldição de um homem irritado. É um presente de uma deusa fêmea benevolente. (tradução nossa) 
brutally, by the straight line of the phallus. And the bleeding was profuse. (HIGHWAY, 2003, p.47) ${ }^{4 \prime}$

Convém lembrar que, pensando o momento histórico literário que permeia o contexto de produção de Alfredo Marien, este se caracteriza, principalmente, a partir da descoberta de novas possibilidades de extração e surgimento de novas colônias com o impulso dado pelo governo Getuliano, pela proposta modernista de nacionalização da literatura, a partir da valorização da terra e de seus elementos. Em Mato Grosso, a literatura desse período, conforme Hilda Magalhães (2004) busca ser fiel à tradição de seu povo. Neste sentido, ao expor o sertanejo que não se adapta à metrópole, partir de um contexto de denúncia social e tratando de um fato econômico, sem deixar o universo lendário de fora, Era um poaieiro se faz um verdadeiro exemplo da literatura dessa época.

A obra desperta um sentimento íntimo em relação à cultura de Mato Grosso, sem, no entanto, ficar restrita à localização espacial já que o tema da busca pela autonomia do homem por meio da natureza, a exploração e o comprometimento com a realidade social excede fronteiras e pode ser compreendida em diversas esferas geográficas.

Destacam-se então, dois contextos de criação totalmente distintos, a própria disposição do mito, no entanto, suscita o mesmo objetivo. Em ambas as civilizações, o mito não só explica a criação do mundo como a organização social e as relações de poder. A possibilidade de atualizar o mito, ajustando-o aos valores e o entendimento de determinado contexto histórico aproxima Era um Poaieiro de outras narrativas, sem, no entanto, deixar de lado os elementos locais, o que atribui originalidade à obra.

Em Brasilino, Marien evoca a figura do sertanejo, a postura do homem ideal. Em um ambiente de total marginalização, o autor demonstra em sua personagem o comportamento esperado ao homem desse meio que, em termos de personalidade, nada tem a ver com o herói antigo, já que este apresenta características humanas como o medo e a preocupação.

Há na escrita de Marien um retorno à origem mitológica, sendo que a atemporalidade do mito se sobressai em relação ao que é histórico, que acaba. Assim, ao pensarmos o substrato mítico por trás da escrita do autor, vamos de encontro com um entendimento distinto. Ao valorizar mais o mítico em detrimento ao histórico, verifica-se a existência de um herói

\footnotetext{
${ }^{4}$ Nesse ponto, o círculo do matriarcado foi perfurado pela linha reta do patriarcado, o círculo do ventre foi perfurado, mais brutalmente, pela linha reta do falo. E o sangramento foi profuso. (tradução nossa)
} 
mais propenso ao modo imitativo elevado, ou seja, mais próximo do divino do que do humano, com suas qualidades e seu caráter incorruptível. Brasilino é a representação de um ideal.

A defesa de que o mito se sobressai tanto em relação à história quanto à própria ficção em Era um poaieiro se pauta na própria proposição mitológica em si. Pensar o mito é pensar a origem, a criação de algo, com o intuito de conciliar o homem com aquilo que ele não pode explicar como se viu no primeiro item do segundo capítulo.

Convém lembrar ainda que, conforme o arqueólogo inglês Arthur Evans (1921) o período minoico, antes da guerra de Tróia, que vigorou na Grécia de 3.100 a 3.000 a. C., foi um período de uma sociedade predominantemente palaciana, com as atividades referentes às navegações enfatizadas, já que o solo de Creta não era propício à agricultura. Com seu declínio, essa sociedade dá lugar a outra que se configura como mais sofisticada: a era micênica.

No caso da sociedade em questão, o mito legitimava as famílias poderosas como descendentes dos deuses. O mito do labirinto mostra a submissão dos povos do continente em relação à Ilha de Creta no tempo Minoico. O próprio Minotauro é representação da dominação, e a morte desse monstro, por sua vez, representa a queda do poder de Creta perante o continente. Assim, o mito na Grécia Antiga ajudou o homem a entender a mobilidade social. A queda da família de Creta e a ascensão de um novo poder constituído. Foi o fim de uma era, consequentemente, o nascimento de outra.

Ao compreender o panorama clássico da presença do mito do labirinto de Creta, podemos relacionar que a morte de Brasilino prefigura os acontecimentos futuros. O fim da extração da poaia representa o início de uma nova era no estado, que mais tarde será conhecido como o maior exportador de grãos do mundo. É a substituição da mão de obra braçal pelas máquinas, da geração de patrões despreocupados com vigor das leis trabalhistas, é a extinção da profissão do poaieiro que, na figura de Brasilino, sucumbe diante da modernização que toma o estado depois do declínio da poaia.

De forma mais ampla, a morte de Brasilino pode ser vista, então, como representação do fim da possibilidade de concretização do mito do Eldorado, uma vez que, a cultura de extração passará por mudanças significativas, principalmente na legislação brasileira, de forma a, cada vez mais, desestimular as expedições informais organizadas pelos sertanejos. Com imposições cada vez mais severas em relação ao meio ambiente e a exploração dos recursos renováveis, as regulamentações se tornarão um 
grande empecilho na vida daqueles que sonham com a fortuna acessível do mito do Eldorado.

Mesmo com alguns dispositivos tipificando agressões ao meio ambiente como o corte de árvores frutíferas, considerado ofensa ao rei Afonso IV e o primeiro Código Criminal tipificar o corte de madeira como ilegal em 1830, as atividades exploratórias só serão observadas pelo Estado no fim da década de 20 que organizará legislação diferenciada, por motivos de preocupação com aquilo que lhe agregava valor econômico. Na Constituição Federal outorgada em 1988 em seu art. 23, o Estado toma para si a responsabilidade de:

VII - preservar as florestas, a fauna e a flora

VI - florestas, caça, pesca, fauna, conservação da natureza, defesa do solo e dos recursos naturais, proteção do meio ambiente e controle da poluição;

Art. 225.

$\S 1^{\circ}$ - Para assegurar a efetividade desse direito, incumbe ao Poder Público:

VII - proteger a fauna e a flora, vedadas, na forma da lei, as práticas que coloquem em risco sua função ecológica, provoquem a extinção de espécies ou submetam os animais a crueldade.

$\S 2^{\circ}$ - Aquele que explorar recursos minerais fica obrigado a recuperar o meio ambiente degradado, de acordo com solução técnica exigida pelo órgão público competente, na forma da lei. $\S 4^{\circ}$ - A Floresta Amazônica brasileira, a Mata Atlântica, a Serra do Mar, o Pantanal Mato-Grossense e a Zona Costeira são patrimônio nacional, e sua utilização far-se-á, na forma da lei, dentro de condições que assegurem a preservação do meio ambiente, inclusive quanto ao uso dos recursos naturais.

Além de tratar o controle dos recursos naturais de forma mais severa, a Constituição determina:
Art. 20 - São bens da União:
IX - os recursos minerais, inclusive os do subsolo;
Parágrafo $1^{\circ}$ - É assegurada, nos termos da lei, aos Estados, ao Distrito Federal e aos Municípios, bem como a órgãos da administração direta da União, participação no resultado da exploração de petróleo ou gás natural, de recursos hídricos para fins de geração de energia elétrica e de outros recursos minerais no respectivo território, plataforma continental, mar territorial ou zona econômica exclusiva, ou compensação financeira por essa exploração.

Ao legislar sobre os recursos naturais e tomar para si a responsabilidade e a posse desses elementos, o estado acaba por desincentivar o trabalhador simples que, ao encontrar jazida, por exemplo, 
deverá acionar o estado para que este tome posse. $\mathrm{O}$ garimpeiro, $\mathrm{o}$ poaieiro, o sertanejo fica cada vez mais sem incentivo para procurar minérios, ou seja, de nada adianta o mito do Eldorado, se ele não pode mais ser aproveitado em virtude da legislação estatal que, ao cuidar dessa parte, libera para as grandes mineradoras, deixando o sertanejo à margem outra vez. É nessa perspectiva que entendemos a morte do mito do Eldorado. O homem simples que busca a possibilidade de mudar de vida sucumbe diante do controle estatal da cultura de exploração.

\section{Considerações finais}

A história da humanidade consagra a fuga para lugares remotos como possibilidade em inúmeras situações de perseguições, tais quais: a inquisição, os escravos, índios. Essas perseguições marginalizavam os perseguidos em locais remotos e de difícil acesso, sendo o sertão matogrossense um exemplo. $\mathrm{O}$ sertão, por sua própria denominação, representa um lugar de fuga, de desconhecido, obscuro, propenso ao sobrenatural. No período da escrita da narrativa em estudo, o predomínio do tema era recorrente na literatura e, possivelmente, deve ter exercido forte influência no escritor francês.

O sertão é compreendido, ainda, como um vazio de civilidade. Para os europeus, qualquer lugar fora da Europa caberia nessa definição, devido à sua população tida como atrasada e sem perspectiva. A nomenclatura podia abordar ainda lugares dentro da própria Europa que fossem distantes das capitais. Um espaço de negação da ordem social. Daí o sertão de Mato Grosso ter chamado a atenção de migrantes brasileiros e, principalmente europeus, pelo extenso território ainda não desbravado, as incontáveis riquezas naturais e as especificidades do povo considerado bárbaro.

Margeadas por tragédias, as páginas que retratam a colonização de Mato Grosso refletem um misto de sentimentos opostos, ao desenhar a província com nuances de céu e inferno. Em uma reatualização do mito do Eldorado e, sobretudo, no século XVIII com o mito da serra dos martírios, Mato Grosso significava para os que vinham de longe a oportunidade de um recomeço, uma vida nova, baseada na possibilidade de fortuna acessível através de grandes achados de recursos naturais que, embora mudando o objeto, seja ouro, diamante, borracha ou poaia, o sonho de mudar de vida foi sempre cultivado no imaginário dos viajantes que chegavam a Mato Grosso.

Dessa forma, o processo de colonização de Mato Grosso, iniciado nos primeiros anos do século XVIII, passou por vários estágios dominados 
pela escrita do olhar estrangeiro, construindo um imaginário semelhante ao da colonização do Brasil. Por outro lado, a manutenção desse olhar persistiu (e ainda persiste em grande escala), mantendo os estereótipos que marginalizam pessoas e condição social. O imaginário do Eldorado foi incentivado, principalmente, pelos políticos, já que a agricultura demandou mão de obra para o povoamento da região que, pela sua localização estratégica, mantinha os interesses dos poderes constituídos.

De forma despretensiosa, Marien traz para o sertão do Mato Grosso a discussão acerca da transição econômica, metaforicamente compreendida na morte da personagem Brasilino, a transformação do mundo, permeada pela memória e o imaginário sertanejo. É como se Mato Grosso da década de 1930 e 1940 repetisse aspectos da colonização do Brasil.

\section{REFERÊNCIAS}

ALENCAR, José de. As Minas de Prata. Vol. 1. $2^{\text {a }}$ Edição. Rio de Janeiro: Livraria José Olympio, 1953.

ARAÚJO, Cristina da Silva. Imaginário e a representação do mito do Eldorado: a crônica de Sir Walter Raleigh-1595. In Revista Tempo Amazônico, p. 25-38, V. I, N 1, 2013.

BACHELARD, Gaston. A poética do espaço. São Paulo: Martins Fontes LTDA, 1996.

BARROS, Abílio Leite. Gente Pantaneira (Crônicas da sua história). Rio de Janeiro, Lacerda Editores, 1998.

BRANDÃO, J. S. Mitologia Grega. Volume 3. Petrópolis: Editora Vozes Ltda, 1987.

BRANDÃO, J. S. Mitologia grega. 1․ Volume. Petrópolis: Editora Vozes, 2002.

CÂMARA CASCUDO, Luís da.Geografia dos mitos brasileiros. São Paulo:

Global, 2002, p. 228-229. 396p

CAMPOS, M. C. A. Pé-de-Garrafa: Uma Face do Arquétipo do Homem Selvagem. Profiscientia (Cuiabá), v. 3, p. 291-308, 2008.

CAMPOS, M. C. A. A lenda do Pé-de-Garrafa. In: XXIII Simpósio Nacional de História, 2005, Londrina. XXIII Simpósio Nacional de História História: Guerra e Paz. Londrina: Anpuh, v. 1. p. 1-8, 2005. 
CARVALHO, Carlos Gomes. Viagens ao Extremo Oeste. Desbravadores, aventureiros e cientistas nos caminhos de Mato Grosso. Cuiabá: Verde Pantanal, 2005.

CASTRILLON-MENDES. Olga Maria. Taunay viajante. Construção imagética de Mato Grosso. Cuiabá: EDUFMT, 2013.

COMMELIN, P. Mitologia grega e romana; tradução Eduardo Brandão. São Paulo: Martins Fontes, 1997.

CONSTITUIÇÃO FEDERAL. BRASIL. Constituição (1988).

CUNHA, A. J. O poaieiro de Mato Grosso. São Paulo: Resenha Triburária, 1981.

CUNHA, Euclides. Os Sertões. São Paulo: Editora Círculo do Livro, 1976.

DUARTE, Noélia. A sobrevivência das origens no conto literário moderno. In: Forma Breve. 223-240, 2013.

ECO, Humberto. História das Terras e lugares lendários. São Paulo: Record, 2013.

ELIADE, M. Mito e realidade. São Paulo: Editora Perspectiva, 1972.

ELIADE, M. Mito do eterno retorno. São Paulo: Mercuryo, 1992.

ELIADE, M. Imagens e Símbolos. Ensaios sobre o simbolismo mágico-religioso. São Paulo: Martins Fontes, 1996.

ELIADE, M. O sagrado e o profano: a essência das religiões. São Paulo: Martins Fontes, 2001.

EVANS, Arthur. The Palace of Minos. London: Macmillan, 1935

GALLETI, L. S. G. Sertão, fronteira, Brasil. Imagens de Mato Grosso no mapa da civilização. Cuiabá: EDUFMT, 2012.

GAGNEBIN, Jeanne Marie. Documentos da Cultura/Documentos da Barbárie. Revista Ide, São Paulo, 2008, 31(46), p. 80-82.

HAMILTON, E. A mitologia. Lisboa: Dom Quixote, 1942.

HOMERO. Odisséia. Lisboa: Livros Cotovia, 2005.

LANGER, Joohnni. O mito do Eldorado: origem e significado no imaginário sulamericano (século XVI). In: Revista de História 136, p. 25-40, 1997. 
LIMA, W. F. Labirinto: a representação do mito de Teseu no Carmen Doctum de Catulo. Dissertação de Mestrado UFMG. 163f. <Disponível em: http:/ / www.bibliotecadigital.ufmg.br/dspace/bitstream/handle/1843/E CAP-6XPECM/disserta_o.pdf?sequence=1> Acesso em: 20 Jul. 2015.

MAGALHÃESS, H. G. D. História da literatura de Mato Grosso: século XX. Cuiabá: Unicen Publicações, 2001.

MARIEN, Alfredo. Era um poaieiro. São Paulo: Editora Técnica, 1944.

ROCHA, E. O que é mito. São Paulo: Brasiliense, 2006.

SCHOLES E KELLOGG. A natureza da narrativa. São Paulo: McGraw-Hill, 1977.

SÜSSEKIND, FLORA. O Brasil não é longe daqui. O narrador, a viagem. São Paulo: Companhia das Letras, 1990.

VILALVA, Walnice. As fronteiras literárias e o romance em Mato Grosso. In: Nódoa no brim. ISSN: 22386457, n²9, 2016.

i E-mail da autora: efnavarro4@gmail.com 